УДК 378,147:37.015.31:7

DOI:

Світлана Ябковська, викладач-методист вищої категорї, циклової комісії народних інструментів Луиьккого педагогічного коледжу

Оксана Шахрай, викладач першої категорії, ичклової комісії фортепіано Луиьького педагогічного коледжу

\title{
ОСОБЛИВОСТІ НАВЧАННЯ ЗА ДОПОМОГОЮ ВСТАНОВЛЕННЯ МІЖПРЕДМЕТНИХ ЗВ'ЯЗКІВ НА ЗАНЯТТЯХ ЕСТЕТИЧНОГО ЦИКЛУ
}

У статті розкрито сутність застосування міжпредметних зв'язків, творчого самовираження особистості. Висвітлено філософські, педагогічні, психологічні погляди на проблему естетичного виховання учнів. Визначено етапи актуалізачії творчого самовираження особистості. Підкреслено значення творчого саморозвитку учня, щуо допомагає йому піднятися на вищий рівень $і$ зуміти безперешкодно виконувати життєво необхідні творчі завдання та проблеми.

Ключові слова: міжпредметні зв 'язки; естетичне виховання; творча самореалізація; самовираження, особистість; компетентність; культура; освіта; духовні ичінності.

Jim. 9.

Svitlana Yabkovska, Lecturer and Methodologist of the high category, Cycle Commission of Folk Instruments Lutsk Pedagogical College Oksana Shakhray, Lecturer, Cycle Commission of Piano Lutsk Pedagogical College

\section{FEATURES OF EDUCATION WITH THE AIDS OF ESTABLISHING THE INTERDISCIPLINARY CONNECTIONS AT AESTHETIC CYCLE LESSONS}

The essence of application of interdisciplinary connections, the creative self-expression of the personality is uncovered in the article. The philosophical, pedagogical, and psychological views on the problem of aesthetic education of students are highlighted. Actualization stages of creative self-expression of personality are determined. The importance of creative self-development of the student is emphasized, which helps to get up to a higher level and to be able to solve vital creative tasks and problems unhindered. Application of different teaching methods, motivation for further increase of socio-cultural knowledge, speech and communicative skills, deepening the pupils' knowledge of the elements of historical and cultural heritage of different cultures and nations.

It is researched that in the process of aesthetic education formation of students, we observe deepening of special and general aesthetic knowledge, acquiring of professional skills and abilities, disclosure of the continuity and perspective development and improvement of personality abilities.

The interdisciplinary connections orientation designed for providing students with systemic knowledge and for formation of the special skills set that gives to those who are learning the opportunity to learn a variety of educational material according to issues of the development of art, culture, education and upbringing of the younger generation, independently, productively and creatively, are proved in the scientific paper.

The realization of tasks according to establishment of interdisciplinary connections at the aesthetic cycle classes is recommended to be based on the unified scientific and pedagogical principles of scientific, systematic, accessible and explicit learning, consciousness and creative cognitive activity, aesthetic needs and artistic taste; an individual approach to students.

The necessity of using different methods of teaching, motivation for further increase of socio-cultural knowledge, speaking and communicative skills, deepening of the pupils' knowledge about the elements of historical and cultural heritage of different countries and people is emphasized.

Keywords: interdisciplinary connections; aesthetic education; creative self-realization; self-expression; personality; competence; culture; education; spiritual values.

П остановка проблеми. Аналіз розвитку людського суспільства показав, що темпи технічного прогресу завжди випереджали його духовний та культурний стан, що призводило до дегуманізації і деморалізації суспільства. У своїх працях філософ Б. Гершунський зазначив, що людина втратила здатність протистояти Злу в усіх його проявах, втратила Віру у моральні, духовні цінності Світу та сенс людського життя, втратила життєві орієнтири й не знаходить відповіді на найважливіші світоглядні питання ні в науці, ні врелігії, нів освіті $[2,23]$.

Перелік знань, умінь і навичок був достатньо стандартизованим i стабільним, що й зумовлювало репродуктивний характер самого процесу навчання. Суть його полягала у створенні механізму передачі знань, умінь та навичок від учителя до учня. При цьому вчитель був їх основним джерелом, а також визначав їх обсяг та методику засвоєння. 
Сьогодні перед освітою України постає завдання виховати людину нової формації (ноосфери) - духовно і естетично багату, морально чисту, високоінтелектуальну, фізично досконалу та відповідальну за власну долю та долю держави.

Аналіз основних досліджень та публікацій. Проблему виховання молоді на засадах духовності, моральності, естетичного сприйняття світу та формування культурних цінностей розглядали філософи, педагоги, психологи та науковці минулого: Я. Коменський, А. Макаренко, С. Русова, В. Сухомлинський, Н. Стельмах, К. Ушинський, С. Шацький та ін. Відомі науковці та педагоги: I. Бех, Є. Бондаревська, Т. Гуменнікова, І. Зезюк, В. Киричок, І. Мар'єнко, Л. Масол, О. Силяєва та ін.зробили значний внесок у вирішення цієї проблеми на сучасному етапі.

Багато українських педагогів - дослідників, таких як В. Байденко, В. Болотов, І. Зимня, А. Хуторський вбачають вихід із цієї ситуації в модернізації змісту освіти, оптимізації технологій освітнього процесу, перегляді мети та результату освіти, а саме у введенні в освіту комплексного підходу та міжпредметних зв'язків.

Питання про міжпредметні зв'язки виникло давно, $з$ введенням роздільного викладання навчальних предметів. Вперше його виявив видатний педагог Я. А. Коменський: "Все, що знаходиться у взаємозв' язку, повинно викладатися у цьому ж зв'язку” [7, 576]. У своїй праці він справедливо вважав, що встановлення зв'язку між навчальними предметами є надзвичайно важливим компонентом для формування системи знань.

Мета статті - розкрити сутність застосування міжпредметних зв'язків для розвитку творчого самовираження особистості, навчити учнів без перешкод виконувати будь-які творчі завдання. Збільшити їх соціокультурні, мовленнєві та комунікативні знання і вміння. Визначити основні етапи актуалізації творчого самовираження.

Виклад основного матеріалу. Міжпредметні зв'язки передбачають взаємну узгодженість змісту матеріалу, його побудову та відбір, що визначаються загальними цілями виховання 3 урахуванням навчально-виховних завдань, зумовлених специфікою кожного навчального предмету. Застосування принципу систематичності не можна обмежувати рамками одного предмету [4, 200]. Він передбачає встановлення між предметних зв'язків, спадкоємність і перспективність розвитку знань та творчих здібностей особистості.
Відомо, що морально-естетичне виховання учнів базується на створенні міжпредметних зв'язків. Метою їх використання є формування художньої культури, естетичної потреби, яку можна визначити, як потребу людини в красі та їі подальшій творчій діяльності за законами краси. Приділяючи увагу двом важливим компонентам: об'єму естетичної потреби, тобто здатності особистості естетично ставитися до, можливо, більш ширшого кола явищ дійсності; та якості естетичної потреби, що виявляється на рівні художнього смаку та сформованого ідеалу. Без перебільшення велике значення у становленні особистості належить морально-естетичному вихованню. Лише за допомогою засобів міжпредметних включень формується невід'ємна підсистема реалізації принципів цілісної системи. Важливою функцією морально-естетичного виховання та художньо-естетичної діяльності учнів $є$ постійна робота над розвитком у них образного мислення [9, 19 - 23]. У художньому образі, як формі уявного мислення, зосереджена інформація про природу, суспільство, людські відносини, традиції, історію та наукові знання. Отже, формування художньої культури має загальний характер, і ця загальність та обов'язковість $€$ найважливішими принципами формування особистості у молодому віці. Лише завдяки комплексному застосуванню міжпредметних включень ми зможемо досягти найбільш ефективних результатів у процесі формування творчої особистості. Система морально-етичного виховання учня повинна вибудовуватися на постійній взаємодії різних видів мистецтв [3, 44].

У процесі художнього виховання необхідно враховувати вікові особливості учня. У ранньому віці дитина не дуже заглиблюється у суть прекрасного, та поверхнево відкриває для себе світ як радісне, повне фарб, руху, звуків ціле, що створене для виконання ії бажань. В цей період здійснюється найбільш інтенсивне формування ставлення до світу, яке поступово трансформується у властивості творчої особистості. Тоді ж закладаються основні морально-естетичні якості, які залишаються незмінними на все життя і впливають на подальше формування світогляду, звичок та переконань. Таке сприйняття світу змінюється 3 настанням підліткового періоду. Різко розширюються вузькі рамки звичного світу. 3'являються нові обов' язки та нова відповідальність і на фоні цього відбувається якісний стрибок у свідомості молодої людини. Переоцінюються колишні цінності, стара форма наповнюється новим 


\section{ОСОБЛИВОСТІНАВЧАННЯ ЗАДОПОМОГОЮ ВСТАНОВЛЕННЯ МІЖПРЕДМЕТНИХ ЗВ'ЯЗКІВ НАЗАНЯТТЯХЕСТЕТИЧНОГОЦИКЛУ}

змістом. Ці перехідні процеси відбуваються і в сфері формування художньої культури. В цей період педагогу необхідно прагнути закласти основи об' єктивного і зацікавленого ставлення до всіх явищ дійсності і мистецтва. А для досягнення цієї мети необхідно вибудувати нову форму проведення уроків типу діалогів мистецтв 3 безпосереднім спілкуванням дітей у створенні нових цілей та завдань.

Чим більше задіяно міжпредметних зв'язків, тим глибше сприймається матеріал, тим краще він відкладається в пам'яті [1, 47]. Отже, найбільша ефективність подачі матеріалу про мистецтво відбувається у їх комплексній взаємодії.

Перед сприйняттям художнього об'єкту учень повинен детально ознайомитись 3 ним за допомогою самостійного опрацювання літературних джерел та використання Інтернет ресурсів. Це допоможе йому відчути думки та почуття автора, сформувати власне ставлення до художнього образу, що є важливою складовою у комплексному сприйнятті мистецтва учнями. Самостійна оцінка художнього об'єкту погано розвинена у школярів, які найчастіше користуються думкою та оцінкою дорослих.

При формуванні художньої культури учнів важливо пам'ятати, що будь-яке відношення має спиратись на розуміння естетичної, історичної та художньої цінності твору, на розуміння того, що даний твір є невід'ємною частиною загальної матеріальної і духовної культурної спадщини нашого суспільства.

При будь-якій роботі зі школярами над творами мистецтва - головний акцент має бути спрямований на естетичне сприйняття самої дійсності, відображеної мистецтвом, а сприйняття мистецтва має розглядатися, перш за все, як засіб активізації естетичного сприйняття реальних об'єктів та подій. Весь цей величезний потенціал сенсорних можливостей організму є необхідною умовою повноцінної зустрічі особистості 3 естетичним об'єктом.

Формування художньої культури учнів може відбуватись практично на всіх заняттях. Вивчаючи найкращі зразки світової літературної, образотворчої та музичної спадщини учні вчаться формувати власну думку, естетично сприймати світ та реалізувати себе, як творчу особистість. Викладачам необхідно проводити спільні з учнями бесіди про мистецтво та створювати нові комплексні освітні програми $[6,35]$. Якомога раніше потрібно починати активно працювати над формуванням художньої культури молоді. Відомо, що морально-естетичне виховання неминуче пов' язане зі сприйняттям мистецтва, складовими якого $є$ аналіз, синтез, розвиток уваги, спостережливість, творча увага, тощо. У сприйнятті художнього об'єкту беруть участь майже всі психічні процеси особистості: відчуття, сприйняття, мислення, воля, емоції, уява. У поліфонії людської психіки, та взаємодії особистості 3 мистецтвом відбувається формування світогляду, морально-етичних якостей та творчих здібностей особистості.

Психологічний механізм сприйняття художнього об'єкту є особливою системою, до складу якої входять дві структури особистості. У першій - виражаються потреби, інтереси, ідеали, що є складовою, власне, динамічної частини цієї системи. У другій - такі психічні процеси, як уява, мислення, відчуття. Повноцінне спілкування зі світом мистецтва багато в чому залежить від людського сприйняття. Почуття кольору, форми, закінченості і рівноваги композиційного розташування об'єктів, почуття “хорошої фігури” і лінії, почуття гармонії і дисгармонії, консонансу і дисонансу, пропорції і багато інших факторів - весь цей величезний потенціал сенсорних можливостей організму $є$ необхідною умовою повноцінної зустрічі особистості з естетичним об'єктом.

Велике значення у виявленні дитячих вражень про мистецтво та активізації відношення до сприйняття художніх образів мають “непрямі" методи: вибір учнями коротких музичних $\mathrm{i}$ поетичних творів, відповідних по естетичному враженню запропонованим творам мистецтва; малюнки по пам'яті на основі побаченого, перегляд циклів картин, фотографій, кінофільмів без розгорнутого словесного коментаря 3 метою накопичення запасу зорових вражень та образів.

Необхідно заохочувати і усні висловлювання учнів, з метою накопичення необхідних термінів 3 області різних видів мистецтва (формат, стиль, образ, розмір, фактура, пропорції, діапазон, розташування...). Але робота зі словом не повинна бути єдиною турботою вчителя, вона повинна поєднуватися з іншими формами роботи над творами мистецтва. Використання міжпредметних зв'язків передбачає максимально широке задіяння різних видів мистецтва шляхом ïx плавного переходу і об'єднання. Наприклад, уроки образотворчого мистецтва дуже вдало поєднуються з уроками музики, етики та світової художньої літератури. Завдання педагога полягає в якомога більш активному використанні всіх доступних педагогічних засобів, щоб у школяра сформувався багатий художній світогляд.

Викладачі повинні не тільки систематизувати 
розрізнені знання про мистецтво, а й організувати роботу по засвоєнню учнями нових знань, отриманню почуттєвого досвіду, естетичних переживань та вражень [8, 112]. Ця робота має бути системною, послідовною, тому потрібно розробити ряд комплексних освітніх програм, що включатимуть у себе всі аспекти педагогічної діяльності з обраних предметів. При плануванні формування художньої культури школяра за допомогою міжпредметних зв'язків необхідно враховувати наступні етапи:

- перш за все необхідно оцінити педагогічну обстановку з точки зору вищих цілей моральноестетичного виховання: виховати гуманну, всебічно розвинену особистість;

- загальна мета повинна бути реалізована в часткових цілях. Формулювання цілей прогнозує діяльність, дозволяє бачити хід і результати навчання. Визначення системи часткових цілей полегшує можливість сформувати систему дій, обрати для них доцільні методи і засоби.

- учитель не повинен забувати і про педагогічну творчість. Це процес взаємозв'язку кількісних і якісних перетворень та змін і на цій основі самовизначення, самовираження i самоствердження особистості вчителя. Без творчості немає руху вперед $[5,195]$.

Для педагогів весь процес формування художньої культури учнів на основі активного використання міжпредметних включень повинен бути чітко спланованим. Особливо продуктивне співробітництво і обмін досвідом між вчителями. При ознайомленні учнів з творами мистецтва майстерність педагога полягає в тому, щоб весь процес сприйняття мистецтва зробити безпосереднім, щоб учні самостійно увійшли в храм мистецтва. Сьогодні вже не можна на одному уроці вчити тільки музиці, а на іншому тільки живопису. Учень повинен отримати всебічну інформацію як про картину, чи музичний твір так і про час їх написання, про історичну добу, про літературу, музику і живопис цього періоду і т.д.

Таким чином вчитель повинен реалізувати три основні групи завдань при ознайомленні учнів 3 будь-яким видом мистецтва за допомогою міжпредметних зв'язків:

1. Освітню;

2. Розвиваючу;

3. Виховну.

Якщо одна 3 цих груп буде слабо виражена, то процес ознайомлення 3 мистецтвом не дасть належних результатів, і учень може зовсім втратити інтерес до вивчення мистецтва.

Висновки та перспективи подальших досліджень. Таким чином можна стверджувати, що визначення міжпредметних зв'язків забезпечило можливість грунтовного дослідження формування художньої культури в учнів. Відбулось виявлення їх індивідуальних особливостей, застосування в навчанні, корегування та подальший розвиток природних даних учнів у процесі вивчення дисциплін естетичного циклу.

У подальшому педагогічне дослідження буде спрямовано на розробку, теоретичне обгрунтування та експерементальну перевірку умов формування міжпредметних зв'язків, створення цілісних уявлень про навчання, позитивну мотивацію необхідності отримання нових знань, бажання до творчості та самостійної діяльності, формування естетичного смаку та різностороннього розвитку особистості.

\section{ЛІТЕРАТУРА}

1. Вороніна Т. П. Освіта в епохунових інформаційних технологій / Т. П. Вороніна. - М.: АМО, 2008. - 147 с.

2. Гершунский Б. С. Философия образования для XXI века: учебное пособие для самообразования / Б. С. Гершунский - М.: Пед. общество России, 2002. $512 \mathrm{c}$.

3. Глинська, Є. А. Міжпредметні звязки в навчанні / Е.А. Глинська, С.В. Титова. - 3-е вид. - Тула: Інфо, 2007. $-44 \mathrm{c}$.

4. Демиденко В. В. Мистецтво у світоглядному вихованні (формування світоглядних уявлень підлітків на уроках літератури, музики, образотворчого мистецтва): навч. посіб. для студ. ВНЗ. - Луганськ: ДЗ “Луганський національний університет імені Тараса Шевченка", 2008. - 200 с.

5. Звєрєв, І.Д. Міжпредметні зв'язки в сучасній школі / І.Д. Звєрєв, В.М. Максимова. 2-е вид. - М.: Педагогіка. $-2006 .-195 \mathrm{c}$.

6. Калюжна Т. Г. Сучасні вимоги до професійної підготовки майбутнього вчителя / Т. Г. Калюжна/ / Наукові записки [Ніжинського державного університету ім. Миколи Гоголя]. Сер.: Психолого-педагогічні науки. - 2013. - № 4 . - С. 32-37.

7. Коменский Я.А. Избранные педагогические сочинения / Я.А.Коменский. - В 2-т. Т 2. - М.: Педагогика, 1982. -576 с.

8. Печерська Є.П. Уроки музики в початкових класах: Навч. посіб. для студ. вищих пед. навч. закл. / Гол. ред. В.М.Куценко. - К.: Либідь, 2001. - С. 271.

9. Смоляга Н. В. Міжпредметні зв'язки як засіб оптимізації навчального процесу/ Н. В. Смоляга // Актуальні проблеми музичної освіти: тем. зб. наук. праць. -Київ, 1990. - С. 15-25.

\section{REFERENCES}

1. Voronina, T. P. (2008). Osvita v epokhu novykh informatsiinykh tekhnolohii [Education in an era of new information technologies]. Moscow: AMO, 147 p. [in Russian].

2. Gershunsky, B. S. (2002). Fylosofyia obrazovanyia 


\section{ОРГАНІЗАЦЯ ОСВІТНЬОГО ПРОЦЕСУЗ ВИКОРИСТАННЯМСИСТЕМИ СИТУАЦЙНИХ ДІАЛОГІЧНИХ ВПРАВ НАУРОКАХ УКРАЇНСЬКОЇ МОВИ В ПОЧАТКОВИХ КЛАСАХ}

dlia XXI veka [Philosophy of education for the $21 \mathrm{st}$ century]. Moscow: Pedagogical Society of Russia, 512 p. [in Russian].

3. Hlynska, Ye. A. \& Tytova, S.V. (2007). Mizhpredmetni zviazky $v$ navchanni [Interpersonal relationships in learning]. Vol.3, Tula: Info, 44 p. [in Russian].

4. Demydenko, V. V. (2008). Mystetstvo u svitohliadnomu vykhovanni (formuvannia svitohliadnykh uiavlen pidlitkiv na urokakh literatury, muzyky, obrazotvorchoho mystetstva [The art of ideological education (formation of philosophical ideas in adolescent class of Literature, Music, Art)]. Educational book for students of Higher Educational Establishments. Luhansk: SE "Luhansk National University named after Taras Shevchenko" Publ., 200 p. [in Ukrainian].

5. Zvieriev, I. D. \& Maksymova, V. M. (2006). Mizhpredmetni zviazky $v$ suchasnii shkoli [Interdisciplinary connections in modern school]. Vol.2, Moskow: Pedahohika, 195p. [in Russian].

6. Kaliuzhna, T. (2013). Suchasni vymohy do profesiinoi pidhotovky maibutnoho vchytelia [Modern requirements for the training of a future teacher]. Scientific notes Nizhyn State University named after Nikolai Gogol. Series: Psychological and pedagogical sciences, no. 4, pp. 32-37. [in Ukrainian].

7. Komenskiy, Ya. A. (1982). Yzbrannye pedagogicheskie sochineniya [Selected pedagogical compositions]. Moskow: Pedahohika, vol. 2, 576 p. [in Russian].

8. Pecherska, Ye. P. (2001). Uroky muzyky v pochatkovykh klasakh [Music lessons in elementary school]. Teach. manual for studio higher ped. tutor shut (Ed.). V. M. Kutsenko. Kyiv: Lybid, p. 271. [in Ukrainian].

9. Smoliaha, N. V. (1990). Mizhpredmetni zviazky yak zasib optymizatsii navchalnoho protsesu [Interdisciplinary relationships as a means of educational process optimization]. Topical issues of musical education: thematic collection of scientific papers. Kyiv, pp. 1525. [in Ukrainian].

Стаття надійшла до редакції 18.10.2018

УДК 373.3.016:811.161.2

DOI:

Надія Ростикус, асистент кафедри початкової $і$ дошкільної освіти Львівського національного університету імені Івана Франка

\section{ОРГАНІЗАЦІЯ ОСВІТНЬОГО ПРОЦЕСУ 3 ВИКОРИСТАННЯМ СИСТЕМИ СИТУАЦІЙНИХ ДІАЛОГІЧНИХ ВПРАВ НА УРОКАХ УКРАЇНСЬКОЇ МОВИ В ПОЧАТКОВИХ КЛАСАХ}

У статті розглянуто прочес формування діалогічного мовлення учнів початкових класів засобом ситуачійних вправ. Розкрито поняття “ситуаційні вправи”. Автором визначено періоди й етапи опанування учнями діалогічного мовлення. Запропоновано систему вправ з метою розвитку діалогічного мовлення учнів. Схарактеризовано особливості організачї̈ навчально-мовленнєвої діяльності відповідно до визначених етапів. Обтрунтовано ефективність навчальних ситуаційних вправ у систематичному застосуванні їх на уроках вивчення лексико-граматичного матеріалу.

Ключові слова: діалог; діалогічне мовлення; ситуачійні вправи; система вправ; період; етап.

Puc. 1. Лim. 5.

Nadiya Rostykus, Assistant of the Elementary and Preschool Education Department Lviv Ivan Franko National University

\section{ORGANIZATION OFTHE EDUCATIONAL PROCESS USING THE SYSTEM OF SITUATIONAL DIALOGICAL EXERCISES AT UKRAINIAN LANGUAGE LESSON AT THE PRIMARY SCHOOL}

In the article, the process of forming the dialogical speech of primary school pupils by means of situational exercises is considered. The concept "situational exercises" is revealed. The author identified the periods and stages of mastering the students' dialogical speech. The system of exercises for the development of the pupils' dialogical speech is proposed based on the competent approach. The peculiarities of the organization of teaching and speech activity according to certain stages are described. It is proved that the system of situational exercises for the purpose of developing the pupils' dialogical speech should consist of exercises from perception through comprehension to expression. The system of exercises includes exercises on the distinction between monologue and dialogical expression, structure analysis and dialogue editing, the use of extra-language means of communication, the formulation of questions and answers, the reorganization of the monologue into dialogue, orientation in the situation of communication, the creation of their own dialogues according to the plot pattern or verbally described situation. The effectiveness of educational situational exercises in the systematic application of them is substantiated. The system of exercises is considered not as supportive of the accelerated rate of development of dialogue speech 